\title{
APPLICATION OF PREFABRICATED CONCRETE IN RESIDENTIAL BUILDINGS AND ITS SAFETY MANAGEMENT
}

\author{
L. JIAO ${ }^{1}$, X.D. LI ${ }^{2}$
}

\begin{abstract}
With the development of the society in recent years, there are more and more housing construction areas. The traditional concrete has not been able to satisfy the demand of housing construction. In this study, prefabricated concrete was applied in the design of assembling style houses considering their characteristics, and its economic, environmental and social benefits were analyzed combining risk matrix evaluation method and management strategy. It was found that the use of prefabricated concrete as a building material could effectively shorten the construction period, reduce the construction cost and improve the construction safety, playing a role of energy saving and environmental protection. Therefore it was concluded that prefabricated concrete can improve the efficiency of construction, reduce environmental pollution and save energy. This work provides a reference for the application of prefabricated concrete in residential buildings and its safety management.
\end{abstract}

Keywords: prefabricated concrete; residential building; safety management

\section{INTRODUCTION}

With the development of industrial architecture, more and more assembling buildings appear which adopts prefabricated concrete to replace traditional cast-in-place concrete [1]. Compared with the traditional cast-in-place concrete, prefabricated concrete has the characteristics of fast construction speed and little pollution [2] and is widely concerned by the public.

\footnotetext{
${ }^{1}$ Master's degree, School of Architecture and Urban Planning, Henan University of Urban Construction, No. 1 Daxiangshan Road, Pingdingshan City, Henan Province, 467036, China, e-mail: leijiao63@sina.com

${ }^{2}$ Master's degree, School of Architecture and Urban Planning, Henan University of Urban Construction, Henan Province, 467036, China.
} 
Many scholars have explored how to effectively apply prefabricated concrete. In order to study the mechanical behaviour of prefabricated concrete shear walls, Zhao et al. [3] carried out Quasi-static experiments on shear walls with different details under low cyclic loading and found that the size of the transverse hole could affect the compression capacity of the walls when the longitudinal bore of the prefabricated concrete was large. In order to control the quality of prefabricated concrete beams, Sun et al. [4] established a computer network curing system and applied database technology and two-dimensional code technology to make prefabricated concrete beams continue to cure. In the study of Nascimbene [5], the composition of the precast concrete frame was strengthened in the construction, including continuous single column and pin end beam, resulting in a high degree of flexibility and low resistance of the inter-beam and interplate connections. With the development of science and technology and the maturity of related theories, the technical level of prefabricated concrete in China has been improved. However, due to the imperfect management and technology, the prefabricated concrete technology cannot give full play to its advantages. Risk management is a very important part of building engineering, which can help project managers to manage the project more scientifically and rationally. Lin et al. [6] identified the risk of JIBAO additional second-line project with fault tree and evaluate railway engineering risk with analytic hierarchy process. Liu et al. [7] put forward the risk management of construction project scheduling based on critical chain which could help efficiently arrange workflow by estimating the deadline of every project under ideal conditions. In this study, the application of prefabricated concrete in practical engineering was analyzed, and moreover the risk management scheme was designed for managing prefabricated concrete projects. The superiority of the technology and the great significances of risk evaluation to engineering management were verified through the analysis on the economic, environmental and social benefits of buildings, which provides a reference for the extensive application of prefabricated concrete engineering combined with risk evaluation.

\section{PRefabricAted CONCRETE AND RESIDENTIAL BUILDINGS}

Prefabricated residential building refers to a residential building built by industrial methods [8], which is composed of assembling parts of or all components of the building transported to the construction site which are prefabricated in the factory [9]. Different parts also need to be casted during construction; therefore prefabricated building is nearly the same with other buildings in 
appearance. Its main characteristics include high construction speed, high safety, less waste, less emission of harmful gas and effective control of cost and quality [10-12].

Differing from the traditional ones, prefabricated housing project put forward higher requirements on the cooperation ability and technical level of the construction team. It is necessary to have a more comprehensive control over the whole engineering process, arrange the working hours of each part reasonably, scientifically divide the personnel and resources, and consider all kinds of problems and prepare the perfect measures in advance. Therefore besides reasonable arrangement of construction, risk evaluation is also needed.

\section{PREFABRICATED CONCRETE PROCESSING AND INSTALLATION METHODS}

This paper mainly described the processing, transportation and installation methods of prefabricated concrete. Prior to the production of prefabricated components, it is necessary to check the technical requirements and quality standards which can help formulate production schemes. Production schemes include production process, production planning, quality control, stacking and transportation. The prefabricated integrated shear wall structure is frequently used in the prefabricated integrated residential buildings in China, which is characterized by easy installation and short construction period.

\subsection{PRoCESSING OF PREFABRICATED BUILDING COMPONENTS}

The components which need to be prefabricated include exterior panels, laminated panels and stairs, and the specific production process is shown in Fig. 1. 


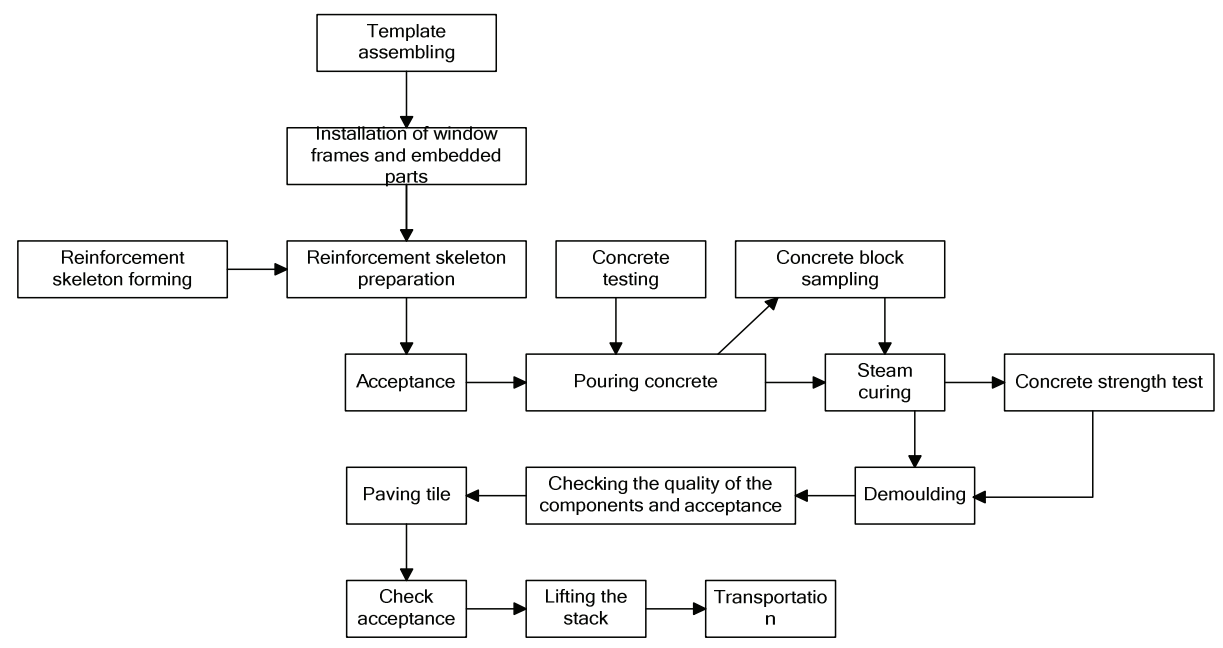

Fig. 1. The manufacturing flow of prefabricated building components

\subsection{TRANSPORT AND STACKING OF COMPONENTS}

Due to the large number of components involved in prefabricated concrete projects, transportation and stacking are more difficult. Safety measures are needed for the stacking of the components. The stacking area also needs to be designed. The specific operation is as follows.

\subsubsection{COMPONENT TRANSPORTATION METHODS}

(1) The vehicle needs to be kept in balance during loading and unloading.

(2) During transportation, the components should be fixed to prevent transformations

(3) During transportation, the corners of the components need to be protected to prevent damage.

\subsubsection{COMPONENT STACKING METHODS}

(1) Locations with good waterproofing facilities are selected for stacking of components and the venue needs to be flat and solid.

(2)The embedded part of the component is faced upwards and the representation position on the component is faced towards the channel direction.

(3)Solid support pads are used to connect the components and the position of the pads should be the same with the position of stripping and lifting. 
(4) When restacking is performed, the pads between the two components need to be aligned and the stacking layer number is set based on the capacity of the pads.

(5) During stacking, corresponding protection measures need to be carried out based on the size of components and the duration of stacking.

\subsection{COMPONENT INSTALLATION METHODS}

The installation of components is difficult and risky. Therefore reasonable and efficient installation methods should be selected. Moreover effective safety management measures should be formulated. The main installation methods are based on shear wall structure, frame structure and frame-shear wall structure. Here shear wall structure is used, and the specific installation flow is shown below.

\subsubsection{EXTERNAL WALL INSTALLATION PROCESS}

Before the installation, whether the information about the component size and reserved burial location is correct needs to be checked. The specific installation steps are as follows.

(1) Axis locationing is used to confirm the mounting position of the prefabricated exterior panel.

(2) The horizontal elevation line is placed stably, and the external wall level control bolts are adjusted.

(3) Cable rope is installed on the prefabricated wall and outer wall panel is lifted.

(4) Professional equipment is used to hook the cable rope and the outer wall panel is pulled to the intended mounting position.

(5) The positioning shaft is used to adjust the horizontal position of the outer wall panel so that the outer wall is closely connected to the channel.

(6) The lower limit end of the external wall is fixed.

(7) The upper and lower bolts of the bead are fixed.

(8) The cable rope is relaxed and then lifted away.

(9) The diagonal member is adjusted, and then the verticality of the outer wall is corrected.

During the installation of the external walls, the following points need to be paid attention to [14-16]. The reserved embedding of the brackets should be noted to ensure that the bracing 
does not break the concrete; trepanning is performed based on the position of the connecting bar; the next step is performed one day after the completion of the installation of the prefabricated components; the elevation of the root of the wall is measured; before wallboard lifting, the root connection position is blocked; a space is reserved to lift the wallboard; the operation of lifting must be slow and cautious; after the lifting is in place, the reflective mirror is used to perform hole matching; correction on left and right side, inner and outer side and perpendicularity is carried out; after the lifting is completed, styrofoam is used to fill the gaps between the wall panels; the inner side of the root is sealed and grouted.

\subsubsection{BALCONY INSTALLATION PROCESS}

(1) The construction and elevation of the balcony composite slabs should meet the requirements of the housing design.

(2) The sponge strips is used to handle the seams of the composite slabs and the outer panel, keeping the thickness of the two members.

(3) After the balcony composite slabs are in place, their locations and elevations are corrected. Then, the reinforcing bars of the composite slabs and the ones within the panel are connected through welding.

(4) Pouring with concrete.

(5) Balcony pouring is performed one day after concrete pouring.

\subsubsection{STAIRCASE INSTALLATION PROCESS}

(1) Stair resting platforms are set up, with the elevation meeting the design requirement.

(2) The elevation and flat seat control lines are used for hoisting the resting platform prefabricated board.

(3) The hidden beam bars are tied, followed by the pouring of dark beam reinforced concrete.

(4) Stair pedal hoisting. 


\subsection{RISK ASSESSMENT}

Risk assessment refers to evaluating the possibilities of risk events and possible consequences in engineering construction and determining the impacts on engineering, staffs and property. Risk matrix [17] is the major risk assessment method currently. Risk matrix is constructed based o the understanding of basic levels of risk indicators and consideration of utility function. Risk assessment is based on Acceptance criteria for construction quality of foundation construction of building foundation (GB50202-2002) [18], Specification for acceptance of construction quality of concrete structures (G50300-2001) [19], Construction specification for bulk concrete (GB50496-2009) [20] and Code for Engineering Surveying (GB50026-2007) [21].

Taking different risk probability grades and risk loss grades into account, a risk matrix was constructed (Table 1).

Table 1. Risk matrix

\begin{tabular}{|c|c|c|c|c|c|}
\hline Risk loss & 1 & 2 & 3 & 4 & 5 \\
\hline 1 & one & one & two & two & three \\
\hline 2 & one & two & two & three & three \\
\hline 3 & two & two & three & three & four \\
\hline 4 & two & two & three & four & four \\
\hline 5 & three & three & four & four & four \\
\hline
\end{tabular}

In Table 1, "one" indicates that the risk is within the acceptable range, the current response is effective and no additional measures are required; "two" indicates that the risk can be conditionally accepted, and the construction side needs to implement preventive measures to improve safety; "three" indicates that the risk can be conditionally accepted, but measures must be taken to tackle the risk; "four" indicates that the risk is unacceptable and must be lowered to below "three"; if the price is too high, the project can be quit.

\section{CONSTRUCTION BENEFIT ANALYSIS}

The aforementioned methods were applied in actual site construction. Then the economic, environmental and social benefits of prefabricated concrete in the construction of residential buildings were analyzed. 


\subsection{ECONOMIC BENEFITS}

The economic benefits of prefabricated concrete were analyzed taking the construction of underground structure of a building as an example. The cost of materials of the building is shown in Table 2.

Table 2. Underground structural material costs of a prefabricated residential building

\begin{tabular}{|c|c|c|}
\hline & Building quantity $\mathrm{m}^{3}$ & Costs (yuan) \\
\hline Timber formwork & $2,611.1352$ & $81,569.66$ \\
\hline Large steel formwork & $2,912.1586$ & $57,422.15$ \\
\hline Price variance & & $24,147.51$ \\
\hline
\end{tabular}

As shown in Table 2, the cost of large steel formwork is much lower than that of timber formwork. It was also found that the construction of large steel formwork could be completed at the construction site, the oddments could be reasonably utilized. The comparison between large steel formwork and timber formwork suggested that the turnover times of the former was more, which saved material cost and chisel load in the late stage. The application of large steel formwork saved 24,147.51 yuan. Compared to the construction process of the traditional cast-in-place structure, the construction process of prefabricated concrete structure saved the time of formwork construction and remvoval, greatly shortening the construction period and the overall cost. Taking effective measures during the construction process can also reduce the waste of materials and save costs. The application of formal fire-fighting pipelines saved 26,931 yuan. Selecting the market which is the closest to the construction site can reduce the cost on transportation. Proper loading and unloading methods can reduce damage, and unloading near the construction site can reduce secondary handling and save labor costs. In this study, the building material market which was $20 \mathrm{~km}$ away from the construction site was chosen, which saved 21,648 yuan compared to the planned 72,500 yuan. In the process of building steel formwork, centralized production and processing at construction sites can effectively improve the utilization rate of excess materials and reduce wastes, and the dimensional accuracy of the vertical structure can avoid plastering, reducing the usage rate of pre-blend mortar and saving cost. 


\subsection{ENVIRONMENTAL BENEFITS}

During the site construction, the construction wastes were counted, and the statistical results are shown in Table 3.

Table 3. Statistics of recycling of construction wastes at the construction site

\begin{tabular}{|c|c|c|c|c|c|c|c|}
\hline $\begin{array}{c}\text { Waste } \\
\text { compositio } \\
\mathrm{n}\end{array}$ & $\begin{array}{c}\text { Brickba } \\
\mathrm{t}\end{array}$ & Concrete & Tube stock & Steel & Mortar & Timber & $\begin{array}{c}\text { Wrapping } \\
\text { paper }\end{array}$ \\
\hline Structure & $82 \mathrm{t}$ & $726 \mathrm{t}$ & $22 \mathrm{t}$ & $469 \mathrm{t}$ & $106 \mathrm{t}$ & $476.33 \mathrm{~m}^{3}$ & $0 \mathrm{t}$ \\
\hline $\begin{array}{c}\text { Decoration } \\
\text { Processing } \\
\text { mode }\end{array}$ & Paving & $\begin{array}{c}\text { Plate } \\
\text { prefabricat } \\
\text { ion }\end{array}$ & Recycling & $\begin{array}{c}\text { Ladder } \\
\text { reinforce } \\
\text { ment }\end{array}$ & Paving & Recycling & $\begin{array}{c}\text { Manufactur } \\
\text { er } \\
\text { repurchase }\end{array}$ \\
\hline $\begin{array}{c}\text { Recycling } \\
\text { amount }\end{array}$ & $63 \mathrm{t}$ & $854 \mathrm{t}$ & $137 \mathrm{t}$ & $403 \mathrm{t}$ & $345 \mathrm{t}$ & $1024 \mathrm{~m}^{3}$ & $18 \mathrm{t}$ \\
\hline $\begin{array}{c}\text { Recycling } \\
\text { rate }\end{array}$ & $76.8 \%$ & $68.43 \%$ & $74.46 \%$ & $85.92 \%$ & $71.43 \%$ & $93.14 \%$ & $100 \%$ \\
\hline
\end{tabular}

As shown in Table 3, the entire construction process caused $3125.598 \mathrm{t}$ of construction waste, including $1690.798 \mathrm{t}$ of building structure waste and $1434.8 \mathrm{t}$ of decoration waste. Moreover 2416.4 $\mathrm{t}$ of construction waste was recycled, and the recycling rate was $77.31 \%$. The recycling rate of all the waste was higher than $70 \%$ except concrete, and the recycling rate of wrapping paper even reached $100 \%$, suggesting that prefabricated concrete could effectively improve the recycling rate of construction waste. 


\subsection{SOCIAL BENEFITS}

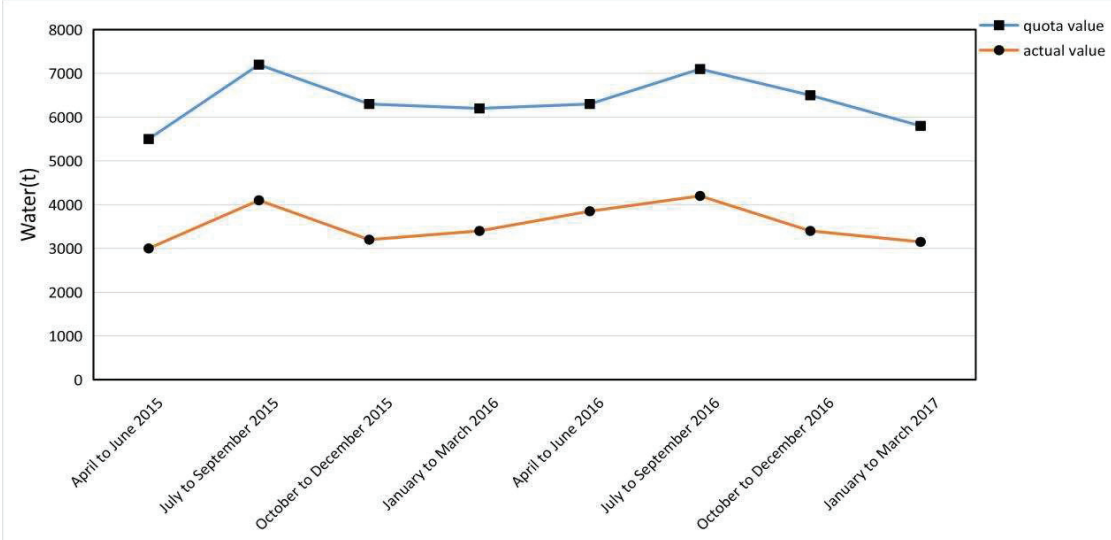

Fig. 2. Quota and actual consumption of water

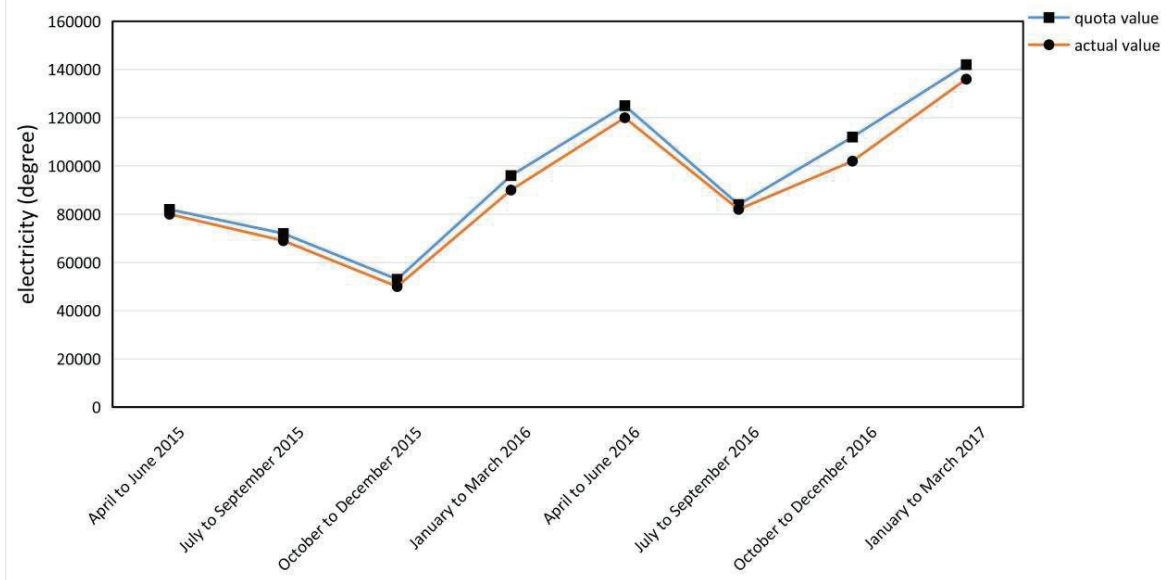

Fig. 3. Quota and actual consumption of electricity

Figure 2 and 3 are the statistical diagrams of water and electricity consumption in site construction. As shown in Figure 3, the actual water consumption value was much smaller than the quota value. There was a peak in water use between July and September every year due to the hot weather. The water consumption between July and September was the largest, which 4,301.27 t in 2015, 3,009.94 $\mathrm{t}$ less compared to the quota value, and 4,217.58 $\mathrm{t}$ in $2016,3,033.86 \mathrm{t}$ less than the quota value. 
Totally 21,981.31 $\mathrm{t}$ of water was saved during construction. The application of prefabricated concrete effectively reduced water consumption. Besides, circulating water systems were installed in wash areas and bathrooms to realize the secondary use of water.

As shown in Figure 3, the actual electricity value was also smaller than the quota value. In the periods between October 2015 and June 2016 and between October 2016 and March 2017, the electricity consumption increased due to the increase of staffs and electricity items. The peak period of electricity consumption was between April and June in 2016 and between January and March in 2017. The actual electricity consumption was 119,012.9 degrees between April and June 2016, and $5,987.1$ degrees were saved compared with the quota value. The actual electricity consumption was 126,314.8 degrees between January and March 2017, and 3,685.2 degrees were saved compared to the quota value. Totally 39,215.2 degrees of electricity was saved during construction. Energysaving equipment and construction progress should be used in the future construction to avoid unnecessary electricity consumption.

\subsection{RISK ASSESSMENT ANALYSIS}

We analyzed several significant risks that are likely to affect the construction process, including prefabricated component transport and storage risk, prefabricated exterior wall waterproofing risk and site construction safety risk. According to the risk matrix analysis, the prefabricated component transport and storage risk is a risk of large probability and it is risk of "second" level in casualties and economic losses, and can be evaded by the aforementioned method.

The prefabricated exterior wall waterproofing risk is also very likely to happen and belongs to level "one" in casualties and "three" in economic losses and should be processed with corresponding measures. The site construction safety risk mainly refers to the accidents during lifting in the site and belongs to level "three" in both casualties and economic losses and should be avoided by formulating corresponding rules. Therefore, the risk matrix can perform a good risk analysis of all events in the construction process so as to formulate corresponding measures to avoid the risks. 


\section{CONCLUSIONS}

The application of prefabricated concrete technology has led to changes in the structural mode of the construction industry, including management mode, design plan and production situation [22]. Prefabricated concrete is used to replace cast-in-place construction methods. Prefabrication and assembling are used to replace on-site mould casting. Residential buildings are built using prefabrication, transportation, lifting and assembled lamp. Prefabricated concrete technology has the characteristics of low cost and short cycle, which can improve industrialization degree and optimize building structure system. It is a scientific and rational means of building [23]. Currently, the prefabricated residential building engineering in China has defects such as imperfect management plan, repeated flow and unfavourable site construction, leading to low working efficiency and increased cost; as a result the advantages of prefabricated concrete is not displayed. Therefore scientific and reasonable management strategies and methods are of great significances to the effective application of prefabricated concrete in engineering construction. Risk assessment of quality, safety, technology in the construction process can help the managers to formulate scientific plans, achieve unified quality, efficiency and safety, and ensure the maximum benefits. In view of the characteristics of the assembly house, the prefabricated concrete was designed, and the corresponding transportation and installation methods were put forward, and risk assessment was carried out using risk matrix in this study. The results demonstrated that the application of prefabricated concrete in the construction of residential buildings could save cost, protect environment, and reduce energy consumption. Moreover the potential safety problems were analyzed using the risk matrix to ensure the safety of construction staffs. The current study verified the prospect of prefabricated concrete in the construction of residential buildings and its great potentials in the future construction market. Studying and learning prefabricated concrete engineering in China and abroad can increase its values. 


\section{REFERENCES}

1. C.G. Kim, H.G. Park, G.H. Hong, S.M. Kang, "Shear Strength of Hybrid Beams Combining Precast Concrete and Cast-In-Place Concrete", Journal of the Korea Concrete Institute, 25(2):175-185, 2013.

2. O. Pons, J.M. Oliva, S.R. Maas, "Improving the Learning Process in the Latest Prefabricated School Buildings", Improving Schools, 13(3): 249-265, 2010.

3. Q. Zhao, Z. Zhang, J. Liu, M. Chu, "Experimental Study on Precast Concrete Shear Walls with Different Hollow Slabs", Open Civil Engineering Journal, 8(1):166-171, 2014.

4. X.B. Sun, S. Li, B. Tian, J. L. Wang, "Study on Precast Concrete Girders Curing System Based on Automatic Drip Irrigation”, Advanced Materials Research, 857(857): 266-270, 2014.

5. R. Nascimbene, E. Brunesi, D. Bolognini, D. Bellotti, "Experimental investigation of the cyclic response of reinforced precast concrete framed structures", Pci J, 60: 57-79, 2015.

6. W. Lin, Y.Q. Li, E. Wang, "Research on Risk Management of Railway Engineering Construction", Systems Engineering Procedia, 1(1): 174-180, 2011.

7. H.B. Liu, "Schedule risk management method of construction project based on critical chain", International Conference on Electric Technology and Civil Engineering, 2561-2563, 2011.

8. X Cao, X Li, Y Zhu, Z. Zhang, "A comparative study of environmental performance between prefabricated and traditional residential buildings in China", Journal of Cleaner Production, 109: 131-143, 2015.

9. K Sandberg, T Orskaug, A Andersson, "Prefabricated Wood Elements for Sustainable Renovation of Residential Building Façades “, Energy Procedia, 96: 756-767, 2016.

10. X. Cao, X. Li, Y. Zhu, Z. Zhang, "A comparative study of environmental performance between prefabricated and traditional residential buildings in China", Journal of Cleaner Production, 109: 131-143, 2015.

11. A. Hisagi, T. Ishikawa, T. Saito, “ 21600 Development of Safe and Secure Environment in High-rise Residential Buildings against Large Earthquakes: Part 9 Possibility on Preparedness and Evacuation Life in High-rise Condominiums", Summaries of technical papers of annual meeting, Architectural Institute of Japan, 1199-1200, 2012.

12. R. Panwar, "Recent Developments, Issues and Challenges for Lithography in ULSI Fabrication", International Journal of Electronics \& Computer Science Engineering, 1(2), 2012.

13. F. Morelli, M. Manfredi, W. Salvatore, "An enhanced component based model for steel connection in a hybrid coupled shear wall structure: Development, calibration and experimental validation”, Computers \& Structures, 176: 50-69, 2016.

14. B. Isik, "Use of prefabricated concrete installation walls for self-built earthen housing projects in the gap region of South-Eastern Turkey", Journal of Environmental Protection \& Ecology, 11(3): 977-985, 2010.

15. T. Cholewa, A. Siuta-Olcha, "Long term experimental evaluation of the influence of heat cost allocators on energy consumption in a multifamily building", Energy \& Buildings, 104(9): 122-130, 2015.

16. E. Radziszewska Zielina, G. Monika, "Studies of the Prefabricated Housing Construction Market in Poland", Selected Scientific Papers - Journal of Civil Engineering, 9(2): 13-26, 2014.

17. I. Mahamid. "Risk matrix for factors affecting time delay in road construction projects: owners' perspective", Applied Mechanics \& Materials, 147(6): 609-617, 2012.

18. Shanghai construction and management committee, "Acceptance criteria for construction quality of foundation construction of building foundation", China planning press, 2002.

19. Y.B. Zhang, "Specification for acceptance of construction quality of concrete structures (gb50204-2002)", Architectural technology, 33 (10): 766-768, 2002.

20. China metallurgical construction association, "Construction specification for bulk concrete", China planning press, 2009.

21. The ministry of housing and urban-rural development of the People's Republic of China, "National standard of the People's Republic of China (GB 50026-2007): Code for Engineering Surveying”, China planning press, 2008.

22. T. Gong, J. Yang, H. Hu, F. Xu, "Construction Technology of Off-Site Precast Concrete Buildings", Frontiers of Engineering Management, 2(2): 122, 2015.

23. D.H. Kim, D.Y. Moon, M.K. Kim, G. Zi, H. Roh, "Experimental test and seismic performance of partial precast concrete segmental bridge column with cast-in-place base”, Engineering Structures, 100: 178-188, 2015. 


\section{LIST OF FIGURES AND TABLES:}

Fig. 1. The manufacturing flow of prefabricated building components

Rys. 1. Przepływ produkcji prefabrykowanych elementów budowlanych

Fig. 2. Quota and actual consumption of water

Rys. 2. Limit i faktyczne zużycie wody

Fig. 3. Quota and actual consumption of electricity

Rys. 3. Limit i faktyczne zużycie energii elektrycznej

Tab. 1. Risk matrix

Tab. 1. Macierz ryzyka

Tab. 2. Underground structural material costs of a prefabricated residential building

Tab. 2. Koszty podziemnych materiałów konstrukcyjnych prefabrykowanego budynku mieszkalnego

Tab. 3. Statistics of recycling of construction wastes at the construction site

Tab. 3. Statystyki recyklingu odpadów budowlanych na placu budowy 


\section{ZASTOSOWANIE PREFABRYKOWANEGO BETONU W BUDYNKACH MIESZKALNYCH I ZARZĄDZANIE JEGO BEZPIECZEŃSTWEM}

Slowa kluczowe: prefabrykowany beton, budynek mieszkalny, zarządzanie bezpieczeństwem

\section{PODSUMOWANIE}

Prefabrykowany beton jest rodzajem betonowej konstrukcji budowlanej, która jest wznoszona poprzez montaż i połączenie prefabrykowanych komponentów. Tego rodzaju prefabrykowane komponenty są produkowane, instalowane i podłączane w trybie fabrycznym. Wymagania jakościowe dla komponentów o odmiennych zastosowaniach są różne podczas prefabrykacji. Oprócz kształtu i wydajności, kontrola jakości obejmuje również złożoność struktury łączącej. W aspekcie budowlanym, jakościowym i środowiskowym, budynki mieszkalne, w których stosuje się prefabrykowany beton, mają więcej zalet niż tradycyjne budynki. Może to skrócić czas budowy, poprawić jakość konstrukcji, ułatwić konserwację na późniejszym etapie oraz przyspieszyć wycofanie funduszy.

W niniejszym badaniu zastosowano prefabrykowany beton podczas projektowania budynków mieszkalnych, a ponadto zastosowano strategię oceny i zarządzania opartą na macierzy ryzyka. W oparciu o teoretyczne podstawy przetwarzania, środków transportu i instalacji, pokazano przykłady podsumowujące zastosowanie prefabrykowanego betonu w budowie budynków mieszkalnych i zarządzaniu jego bezpieczeństwem.

Przeanalizowano charakterystykę prefabrykowanych budynków mieszkalnych. Rozsądnie zaaranżowano cały proces inżynieryjny, obejmujący obróbkę, transport, układanie w stos i instalację komponentów, takich jak ściany zewnętrzne, balkon i schody. Niektóre procedury operacyjne zostały powiązane z problemami występującymi w budownictwie. Ryzyko związane z inżynierią budowlaną zostało ocenione na podstawie szeregu rozporządzeń wydanych przez rząd. W oparciu o podsumowanie cennych badań, zastosowano macierz ryzyka dla zarządzania ryzykiem w projekcie budowlanym. Z zastosowaniem kryteriów akceptacji dla jakości konstrukcji fundamentowej budynku (GB50202-2002), specyfikacji dotyczącej akceptacji jakości konstrukcji betonowej (G50300-2001), specyfikacji konstrukcji dla betonu monolitycznego (GB50496-2009) oraz kodeksu inżynierii geodezyjnej (GB50026-2007) jako odniesień, ryzyko budowlane zostało podzielone na cztery stopnie kompleksowego prawdopodobieństwa wystąpienia ryzyka oraz klasy ryzyka.

Przeanalizowano ekonomiczne, środowiskowe i społeczne korzyści z prefabrykowanego betonu we wznoszeniu budynków mieszkalnych, poprzez analizę rzeczywistego projektu budowlanego. Drewniane i stalowe konstrukcje zostały porównane podczas wznoszenia konstrukcji podziemnej. Stwierdzono, że konstrukcja stalowa przynosi większe obroty, zaoszczędza więcej kosztów materiałowych i daje lepszy efekt budowlany. Oprócz betonu, wskaźnik ponownego wykorzystania innych odpadów przekroczył 70\%. W odniesieniu do świadczeń socjalnych, rzeczywiste zużycie wody i energii było znacznie mniejsze niż limit.

Niektóre punkty tego badania wymagają dalszego ulepszania. Na przykład, analiza konstrukcyjnej standardyzacji została ograniczona. Bardziej odpowiednie standardy z Chin lub innych krajów powinny zostać porównane w celu poznania zaawansowanych technik budowlanych. Internet oraz technologia mogą być wykorzystane do lepszego zarządzania podczas wznoszenia prefabrykowanej konstrukcji betonowej, optymalizacji nadzoru nad budownictwem inżynieryjnym, stworzenia nowego trybu budownictwa oraz zdania sobie sprawy z głębokiego, szybkiego rozwoju sieci i prefabrykowanego budynku. 